\title{
Mechanism of the Reaction of Nitric Oxide, Ammonia, and Oxygen over Vanadia Catalysts. 2. Isotopic Translent Studies with Oxygen-18 and Nitrogen-15 ${ }^{\dagger}$
}

\author{
Frans J. J. G. Janssen,* Frans M. G. van den Kerkhof, \\ Department of Chemical Research, N. V. KEMA, R\& D Division, Arnhem Institutions of the Dutch Electricity \\ Utilities, 6800 ET Arnhem, The Netherlands
}

Hans Bosch, and Julian R. H. Ross

Department of Chemical Technology, Twente University of Technology, 7500 AE Enschede, The Netherlands (Received: March 5, 1987; In Final Form: July 15, 1987)

\begin{abstract}
The mechanism of nitric oxide reduction with ammonia to form $\mathrm{N}_{2}, \mathrm{H}_{2} \mathrm{O}$, and $\mathrm{N}_{2} \mathrm{O}$ both in the presence and in the absence of $\mathrm{O}_{2}$ over the following series of catalysts, unsupported $\mathrm{V}_{2} \mathrm{O}_{5}, \mathrm{~V}_{2} \mathrm{O}_{5}$ on $\mathrm{TiO}_{2}, \mathrm{~V}_{2} \mathrm{O}_{5}$ on $\mathrm{SiO}_{2} / \mathrm{Al}_{2} \mathrm{O}_{3}$, and $\mathrm{V}_{2} \mathrm{O}_{5}$ on $\mathrm{Al}_{2} \mathrm{O}_{3}$, has been investigated with the aid of labeled $\mathrm{O}_{2}$ and labeled $\mathrm{NH}_{3}$ at $400{ }^{\circ} \mathrm{C}$. The behavior of ammonia was studied both in the presence and in the absence of $\mathrm{O}_{2}$. The presence of labeled $\mathrm{O}_{2}$ gives extra information about the product distribution and the reaction mechanism. Evidence is given that ammonia does not react with $\mathrm{O}_{2}$ or $\mathrm{O}$ from any source during the reaction, but that nitrogen and nitrous oxide were produced by a reaction involving all three species, $\mathrm{NO}, \mathrm{NH}_{3}$, and/or $\mathrm{O}_{2}$. $\mathrm{Nitrous}$ oxide and water are both formed at two different sites of the catalyst. A series of transient tracing studies were performed in a plug-flow reactor using ${ }^{15} \mathrm{NH}_{3}$ and ${ }^{18} \mathrm{O}_{2}$. Both ${ }^{15} \mathrm{NN}$ and ${ }^{15} \mathrm{NNO}$ were produced on the unsupported $\mathrm{V}_{2} \mathrm{O}_{5}, \mathrm{~V}_{2} \mathrm{O}_{5}$ on $\mathrm{TiO}_{2}, \mathrm{~V}_{2} \mathrm{O}_{5}$ on $\mathrm{SiO}_{2} / \mathrm{Al}_{2} \mathrm{O}_{3}$, and $\mathrm{V}_{2} \mathrm{O}_{5}$ on $\mathrm{Al}_{2} \mathrm{O}_{3}$ with very high selectivities. The mechanism of the reaction of $\mathrm{NO}, \mathrm{NH}_{3}$, and $\mathrm{O}_{2}$, proposed in a previous paper (ref 2 ), is further evaluated on the basis of this new experimental evidence.
\end{abstract}

\section{Introduction}

It was found in a previous study by Bosch et al. ${ }^{1}$ that the steady state of the reduction of $\mathrm{NO}$ by $\mathrm{NH}_{3}$ to form $\mathrm{N}_{2}$ and $\mathrm{H}_{2} \mathrm{O}$ is reached only after about $50 \mathrm{~min}$ in the absence of oxygen over a $\mathrm{V}_{2} \mathrm{O}_{5}$ on $\mathrm{TiO}_{2}$ catalyst. Moreover, during this induction period the consumption of ammonia was considerably higher than that in the steady state and the production of water went through a maximum. Furthermore, it was concluded for monolayer catalysts that oxygen from the underlying layers does not play an important role in the overall reaction. In situ temperature-programmed reduction measurements with hydrogen ${ }^{1}$ showed that the surface of the catalyst had been reduced after the reduction of NO with $\mathrm{NH}_{3}$ had been carried out.

In the preceding study, ${ }^{2}$ we described the role of oxygen in the selective catalytic reduction of nitric oxide with ammonia. It was assumed there that both the chemisorbed ammonia species and the physisorbed ammonia species are able to react with nitric oxide via an Eley-Rideal mechanism. Chemisorbed ammonia species are defined here as being nitrogen-hydrogen-containing species present on the surface during the reaction at $400^{\circ} \mathrm{C}$. Physisorbed ammonia species are the result of the reaction of $\mathrm{OH}$ groups present on the surface with $\mathrm{NH}_{3}$. Two "types" of water are formed: that originating from the reaction of gaseous NO with the chemisorbed ammonia species and that formed as a result of the dehydration of $\mathrm{OH}$ groups present on the surface of the catalyst. Thus, lattice oxygen shared with adjacent sites was involved in the reaction. Furthermore, it was shown that gaseous oxygen could be exchanged with the lattice oxygen of the catalyst during reaction in the temperature region of $300-400{ }^{\circ} \mathrm{C}$. Scrambling of NO with $\mathrm{V}=\mathrm{O}$ groups was also observed. However, the role of ammonia and of nitric oxide in the formation of $\mathrm{N}_{2} \mathrm{O}$ was not clear and only a suggestion of the mechanism was given. The behavior of ammonia during the reaction and its ability to reduce the surface of the catalyst before the reaction can give valuable information about the reaction mechanism. The present paper thus describes an investigation of the mechanism of the reduction of NO with ${ }^{15} \mathrm{NH}_{3}$ or ${ }^{14} \mathrm{NH}_{3}$ in the presence of ${ }^{16} \mathrm{O}_{2}$ or ${ }^{18} \mathrm{O}_{2}$ at concentration levels of about $500 \mathrm{ppm}$ using a plug-flow reactor; the catalysts used were unsupported $\mathrm{V}_{2} \mathrm{O}_{5}, \mathrm{~V}_{2} \mathrm{O}_{5}$ on $\mathrm{TiO}_{2}$, $\mathrm{V}_{2} \mathrm{O}_{5}$ on $\mathrm{Al}_{2} \mathrm{O}_{3}$, and $\mathrm{V}_{2} \mathrm{O}_{5}$ on $\mathrm{SiO}_{2} / \mathrm{Al}_{2} \mathrm{O}_{3}$ catalysts. From the measured product distributions, it was possible to deduce reaction

\footnotetext{
${ }^{\dagger}$ For part 1, see ref 2 .
}

TABLE I: Catalysts Used in This Study ${ }^{2}$

\begin{tabular}{clccl}
\hline no. & \multicolumn{1}{c}{ catalyst } & $\begin{array}{c}\text { vanadium } \\
\text { content, } \%\end{array}$ & $S_{\mathrm{BET}}, \mathrm{m}^{2} / \mathrm{g}$ & $\begin{array}{c}\text { particle } \\
\text { size, } \mathrm{mm}\end{array}$ \\
\hline 1 & $\mathrm{~V}_{2} \mathrm{O}_{5} / \mathrm{TiO}_{2}$ & 1.9 & 45 & $0.3-0.6$ \\
2 & $\mathrm{~V}_{2} \mathrm{O}_{5} / \mathrm{SiO}_{2} / \mathrm{Al}_{2} \mathrm{O}_{3}$ & 5.6 & 140 & $0.25-0.5$ \\
3 & $\mathrm{~V}_{2} \mathrm{O}_{5} / \mathrm{Al}_{2} \mathrm{O}_{3}$ & 8 & 170 & $0.25-0.5$ \\
4 & $\mathrm{~V}_{2} \mathrm{O}_{5} / \mathrm{Al}_{2} \mathrm{O}_{3}$ & 4.4 & 207 & $0.25-0.5$ \\
5 & $\mathrm{~V}_{2} \mathrm{O}_{5}$ & 58 & 10.5 & $0.25-0.5$
\end{tabular}

paths. All the catalysts were studied at $400^{\circ} \mathrm{C}$, at which temperature nitrous oxide is produced; observations made on the production of the nitrous oxide contribute to a better understanding of the mechanism of the overall reaction. The effect of ammonia on the catalysts in the absence of nitric oxide and oxygen was also studied. The results are used to give further support for a mechanism proposed previously. ${ }^{2}$

\section{Experimental Section}

Catalysts. The catalysts used in this study and their main characteristics are summarized in Table I. Other experimental details are described in the preceding paper. ${ }^{2}$ Prior to the NO reduction experiments, the catalyst samples were calcined in situ with helium containing $25 \%$ oxygen at $300-400{ }^{\circ} \mathrm{C}$.

Gases. ${ }^{15} \mathrm{NH}_{3}$ and ${ }^{18} \mathrm{O}_{2}$ (isotopic purity 99 atom \%) were obtained from MSD isotopes (Canada) and were used without further purification. Gas mixtures of ${ }^{15} \mathrm{NH}_{3}, \mathrm{O}_{2}$, and ${ }^{18} \mathrm{O}_{2}$ with helium up to $10 \mathrm{MPa}$ with concentrations of about 1000-2000 ppm were prepared by conventional static gravimetric methods in our laboratory. Various mixtures of $\mathrm{NO}, \mathrm{NH}_{3}$, and $\mathrm{O}_{2}$ were established with the aid of mass flow controllers (Matheson). It was not possible to carry out experiments in the complete absence of oxygen as trace quantities (1-5 ppm) were always present in the different gas streams. Thus, the description in the text "in the absence of oxygen" means that there was no oxygen added to the gas mixture. Mass spectrometric peaks were examined up $m / e 48\left({ }^{15} \mathrm{~N}_{2}{ }^{18} \mathrm{O}\right)$. The masses of ${ }^{15} \mathrm{NH}_{3} m / e 18$ and ${ }^{15} \mathrm{~N}_{2} m / e$ 30 coincide with those of $\mathrm{H}_{2} \mathrm{O}$ and $\mathrm{NO}$ and the quantities of these species were therefore determined from the nitrogen material

(1) Bosch, H.; Janssen, F.; van den Kerkhof, F.; Oldenziel, J.; van Ommen, J. G.; Ross, J. R. H. Appl. Catal. 1986, 25, 239.

(2) Janssen, F. J. J. G.; van den Kerkhof, F. M. G.; Bosch, H.; Ross, J. R. H. J. Phys. Chem., in press. 


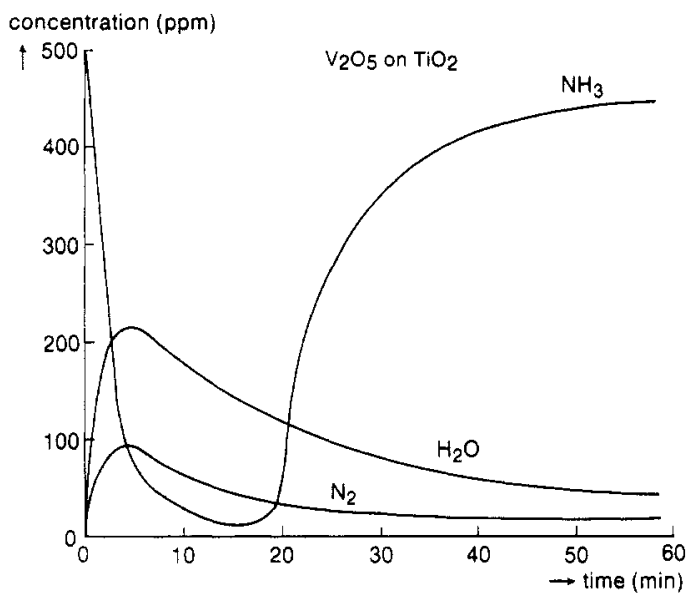

Figure 1. The reaction of ammonia with the $\mathrm{V}_{2} \mathrm{O}_{5}$ on $\mathrm{TiO}_{2}$ catalyst at $400^{\circ} \mathrm{C}$. $\left[\mathrm{NH}_{3}\right]_{i}=500 \mathrm{ppm}, 100 \mathrm{mg}$ of catalyst, balance helium.

balance and the results of reactions carried out without tracers.

Apparatus and Procedures. The apparatus used and the procedures adopted are essentially those described previously. ${ }^{2}$ During the calibration of the mass spectrometer with known mixtures of $\mathrm{NO}, \mathrm{NH}_{3}$, and $\mathrm{O}_{2}$, helium was passed over the catalyst. After the calibration, the eight-port valve (shown in Figure 1 of ref 2) was switched and the helium stream was replaced by the calibration mixture. There is thus always a deviation in the response caused by flushing helium from the reactor (see Results).

Three distinct types of experiments have been carried out: (1) after the reduction of the catalyst with ammonia at $400^{\circ} \mathrm{C}, \mathrm{NO}$ was introduced on the catalyst and the resulting reaction products were measured by the mass spectrometer; (2) the same type of experiment was repeated with a prereduced catalyst, admitting a mixture of $\mathrm{NO}$ and $\mathrm{NH}_{3}$; and (3) as in (2) but with a $\mathrm{NO} /$ $\mathrm{NH}_{3} / \mathrm{O}_{2}$ mixture. Various combinations of labeled molecules were used and experiments were also carried out in which the isotopic composition was changed in step functions.

\section{Results and Interpretation}

Three types of experiments have been carried out on the catalysts $\mathrm{V}_{2} \mathrm{O}_{5}$ on $\mathrm{TiO}_{2}$ and $\mathrm{V}_{2} \mathrm{O}_{5}$ on $\mathrm{Al}_{2} \mathrm{O}_{3}$ which were previously reduced by $\mathrm{NH}_{3}$ or ${ }^{15} \mathrm{NH}_{3}$ at $400{ }^{\circ} \mathrm{C}$. In the first type of experiment the prereduced catalyst sample was flushed with helium in order to remove physisorbed ammonia from the walls of the tubing and other parts of the experimental system, and then exposed to NO. In the second type, the reaction of $\mathrm{NO}$ with $\mathrm{NH}_{3}$ was examined over the reduced catalyst, while in the third type, $\mathrm{O}_{2}$ was added to the $\mathrm{NO}$ and $\mathrm{NH}_{3}$ reaction mixture, again over the reduced catalyst.

Reduction of the Catalysts with $\mathrm{NH}_{3}$. Figure 1 shows the concentration profiles for the compounds $\mathrm{NH}_{3}, \mathrm{~N}_{2}$, and $\mathrm{H}_{2} \mathrm{O}$ obtained during the reduction with ammonia of the catalyst $\mathrm{V}_{2} \mathrm{O}_{5}$ on $\mathrm{TiO}_{2}$. After $20 \mathrm{~min}$, during which time all the ammonia was used, ammonia appeared in the effluent stream: however, the reaction was still not complete even after $60 \mathrm{~min}$. Ammonia was thus oxidized by the catalyst surface, resulting in the products nitrogen and water. The curves of water and nitrogen were graphically integrated between 0 and $60 \mathrm{~min}$ and the ratio of the amounts of water and nitrogen was found to be about 3 and is in agreement with the stoichiometry

$$
3[\mathrm{O}]+2 \mathrm{NH}_{3} \rightarrow \mathrm{N}_{2}+3 \mathrm{H}_{2} \mathrm{O}
$$

where [O] represents the amount of oxygen available from the catalyst. For this experiment, [O] was about $25 \mu \mathrm{mol}$ of oxygen, and this quantity can be compared with $93 \mu \mathrm{mol}$ of oxygen present in the $\mathrm{V}_{2} \mathrm{O}_{5}$ part of the catalyst. Hence one of the five oxygen atoms of each $\mathrm{V}_{2} \mathrm{O}_{5}$ species is removed, assuming that the $\mathrm{V}_{2} \mathrm{O}_{5}$ is present on the catalyst surface, that the $\mathrm{TiO}_{2}$ does not take part in the oxidation of the ammonia, and that oxygen removal is uniform across the surface of the catalyst. From the measured amounts of water and nitrogen, it could also be calculated that

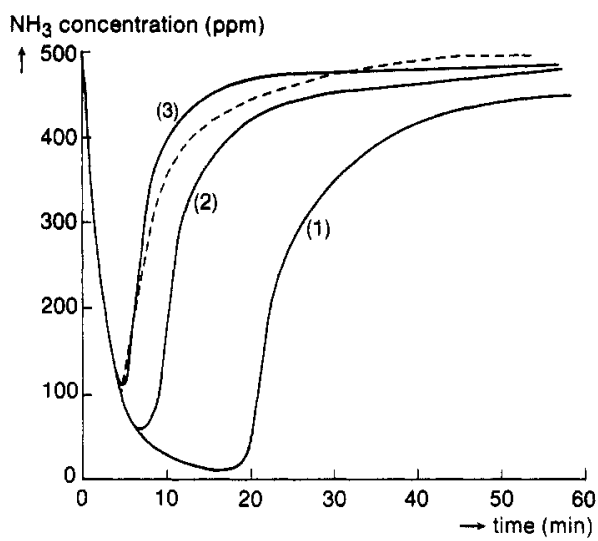

Figure 2. Concentration profiles of ammonia as a function of time on the $(50 \mathrm{mg}) \mathrm{V}_{2} \mathrm{O}_{5}$ on $\mathrm{TiO}_{2}$ catalyst at $400^{\circ} \mathrm{C}$. The experiments were carried out successively. Curve 1: Concentration profile of ammonia on a freshly calcined catalyst $\left(1 \mathrm{~h}\right.$ oxygen at $\left.300^{\circ} \mathrm{C}\right)$. Curve 2: The profile after the catalyst was flushed with helium during one hour at $400^{\circ} \mathrm{C}$. Curve 3 is determined after the catalyst was flushed with helium for 10 $\mathrm{h}$ at $400^{\circ} \mathrm{C}$. The dotted line is the breakthrough curve of ammonia for an empty reactor.

the consumption of $\mathrm{NH}_{3}$ by the catalyst was about $0.4 \mathrm{~mol}$ of $\mathrm{NH}_{3}$ per mole of $\mathrm{V}$.

After the catalyst was flushed with helium at $400^{\circ} \mathrm{C}$ for $1 \mathrm{~h}$, ammonia was reintroduced. Further reaction occurred; the consumption of $\mathrm{NH}_{3}$ is shown by curve 2 of Figure 2, where it is compared with the equivalent curve for the fresh catalyst (curve 1 , taken from Figure 1). When this procedure was repeated, with the difference that the catalyst was now flushed for $10 \mathrm{~h}$ with helium, the results of curve 3 were obtained. Curve 3 fits roughly on the breakthrough curve (dotted line) obtained when ammonia was fed to the empty reactor, indicating that no further reaction occurred in the experiment of curve 3 and that the catalyst had become inactive further the reduction by $\mathrm{NH}_{3}$. These results were confirmed by thermogravimetric measurements, which indicated that the catalyst could be reduced by ammonia to V(IV). From the ammonia profiles of Figure 1 and 2, it was not possible to calculate the amount of ammonia left behind on the surface of the catalyst.

The Reaction of NO with the Prereduced Catalyst. In the following three types of experiments the catalysts $\mathrm{V}_{2} \mathrm{O}_{5}$ on $\mathrm{Al}_{2} \mathrm{O}_{3}$ (no. 4) and $\mathrm{V}_{2} \mathrm{O}_{5}$ on $\mathrm{TiO}_{2}$ were reduced with ${ }^{15} \mathrm{NH}_{3}$ at $400{ }^{\circ} \mathrm{C}$. ${ }^{15} \mathrm{NH}_{3}$ was used instead of $\mathrm{NH}_{3}$ in order to distinguish between the nitrogen compounds which occur from subsequent reaction of NO with adsorbed nitrogen species or with the surface of the catalyst. The number of moles of $\mathrm{NH}_{3}$ consumed per mole of $\mathrm{V}$ by the catalysts $\mathrm{V}_{2} \mathrm{O}_{5}$ on $\mathrm{Al}_{2} \mathrm{O}_{3}$ (no. 4) and $\mathrm{V}_{2} \mathrm{O}_{5}$ on $\mathrm{TiO}_{2}$ were found to be 0.16 and 0.40 , respectively. These values were corrected for the number of micromoles of $\mathrm{NH}_{3}$ which reacted with gaseous oxygen already present in the gas mixtures. After the reduction, the catalysts were flushed with helium at $400^{\circ} \mathrm{C}(1$ or $3 \mathrm{~h}$ ). NO was then introduced, and this was found to reoxidize the catalyst, giving $\mathrm{N}_{2}$ as predominant product. During this reaction on the catalyst $\mathrm{V}_{2} \mathrm{O}_{5}$ on $\mathrm{Al}_{2} \mathrm{O}_{3}$ (no. 4 ), ${ }^{15} \mathrm{NN},{ }^{15} \mathrm{NNO}$, $\mathrm{H}_{2} \mathrm{O}$, and $\mathrm{O}_{2}$ were also found in the exhaust gas. From the quantity of ${ }^{15} \mathrm{NN}$ found in this experiment it can be calculated that about $20 \%$ of the ammonia reacted was still present as a ${ }^{15} \mathrm{~N}$-containing species on the prereduced catalyst before the reaction. These species disappeared when the catalyst was heated in helium at $400{ }^{\circ} \mathrm{C}$ for prolonged times. This was also found to be the case for a similar experiment on the $\mathrm{V}_{2} \mathrm{O}_{5}$ on $\mathrm{TiO}_{2}$ catalyst; with this only small amounts of $\mathrm{N}_{2}\left(10^{-9} \mathrm{~mol}\right)$ and $\mathrm{N}_{2} \mathrm{O}$ $\left(10^{-10} \mathrm{~mol}\right)$ were found.

The Reaction of $\mathrm{NO}$ and $\mathrm{NH}_{3}$ with the Prereduced Catalyst. To study the effect of the reduced surface on the reaction of NO and $\mathrm{NH}_{3}$, the catalyst $\mathrm{V}_{2} \mathrm{O}_{5}$ on $\mathrm{TiO}_{2}$ (no. 1, Table I) was reduced with $\mathrm{NH}_{3}$ at $400^{\circ} \mathrm{C}$ for $13 \mathrm{~h}$. After the reduction, a mixture of $\mathrm{NO}$ and $\mathrm{NH}_{3}$ was introduced to the catalyst and the products nitrogen, nitrous oxide, and water were formed. As is shown in Figure 3, a high initial activity in the absence of oxygen was 
TABLE II: Distribution of the Nitrogen-Containing Products of the Reaction of Nitric Oxide, Ammonia, and Oxygen at the Steady State during Transient Tracer Experiments ${ }^{a}$

\begin{tabular}{|c|c|c|c|c|c|c|c|c|c|c|c|c|c|c|c|c|}
\hline & & \multicolumn{15}{|c|}{ catalyst (no.) } \\
\hline & & \multicolumn{3}{|c|}{$\mathrm{V}_{2} \mathrm{O}_{5} / \mathrm{TiO}_{2}(1)$} & \multicolumn{3}{|c|}{$\begin{array}{c}\mathrm{V}_{2} \mathrm{O}_{5} / \mathrm{SiO}_{2} / \mathrm{Al}_{2} \mathrm{O}_{3} \\
(2)\end{array}$} & \multicolumn{3}{|c|}{$\mathrm{V}_{2} \mathrm{O}_{5} / \mathrm{Al}_{2} \mathrm{O}_{3}(3)$} & \multicolumn{3}{|c|}{$\mathrm{V}_{2} \mathrm{O}_{5} / \mathrm{Al}_{2} \mathrm{O}_{3}(4)$} & \multicolumn{3}{|c|}{$\mathrm{V}_{2} \mathrm{O}_{3}(5)$} \\
\hline & & I & $\mathrm{II}^{b}$ & III & I & II & III & I & II & $\overline{\text { III }}$ & $I$ & II & III & I & II & III \\
\hline \multicolumn{2}{|c|}{ time ${ }^{c}$ min } & 280 & 300 & 500 & 300 & 500 & 700 & 300 & 500 & 700 & 300 & 500 & 700 & 300 & 500 & 700 \\
\hline \multicolumn{17}{|l|}{$(m / e)$} \\
\hline 28 & $\mathbf{N}_{2}$ & 73.9 & 43.4 & 2.5 & 78.3 & 7.6 & 5.5 & 85.4 & 14.8 & 4.2 & 81.4 & 14.6 & 0.8 & 29.0 & 12.4 & 6.3 \\
\hline 29 & ${ }^{15} \mathrm{NN}$ & 0 & 34.9 & 73.0 & 0 & 73.3 & 86.9 & 0 & 72.8 & 92.3 & 0 & 71.7 & 95.4 & 0 & 20.7 & 27.9 \\
\hline 32 & $\mathrm{~N}^{18} \mathrm{O}$ & 4.5 & $4: 8$ & 0 & 14.4 & 14.0 & 0 & 11.6 & 10.6 & 0 & 14.2 & 11.6 & 0 & 23.7 & 22.8 & 0 \\
\hline 44 & $\mathrm{~N}_{2} \mathrm{O}$ & 14.9 & 7.3 & 1.7 & 6.1 & 0.3 & 0 & 1.7 & 0 & 0.4 & 4.4 & 0.3 & 0.4 & 32.0 & 1.7 & 1.9 \\
\hline 46 & $\mathrm{~N}_{2}^{18} \mathrm{O}$ & 6.7 & 2.5 & 0 & 1.3 & 0 & 0 & 0.3 & 0 & 0 & 0 & 0 & 0 & 15.3 & 1.9 & 2.7 \\
\hline 45 & ${ }^{15} \mathrm{NNO}$ & 0 & 5.7 & 22.8 & 0 & 4.9 & 7.6 & 0 & 1.8 & 3.1 & 0 & 1.7 & 3.4 & 0 & 27.8 & 61.2 \\
\hline 47 & ${ }^{15} \mathrm{NN}^{18} \mathrm{O}$ & 0 & 1.4 & 0 & 0 & 0 & 0 & 0 & 0 & 0 & 0 & 0 & 0 & 0 & 12.7 & 0 \\
\hline 18 & $\mathrm{H}_{2} \mathrm{O}$, ppm & 432 & 500 & 578 & 341 & 341 & 482 & 459 & 445 & 486 & 309 & 285 & 350 & 365 & 325 & 500 \\
\hline 20 & $\mathrm{H}_{2}{ }^{18} \mathrm{O}, \mathrm{ppm}$ & 263 & 236 & 6 & 111 & 111 & 21 & 100 & 89 & 21 & 70 & 70 & 2 & 229 & 234 & 18 \\
\hline \multicolumn{2}{|c|}{ conversion, $\%$} & 85 & 81 & 78 & 53 & 51 & 52 & 51 & 50 & 55 & 56 & 56 & 57 & 33 & 29 & 36 \\
\hline \multicolumn{2}{|c|}{ selectivity } & 0.76 & & 0.76 & 0.84 & & 0.92 & 0.91 & & 0.97 & 0.88 & & 0.97 & 0.33 & & 0.31 \\
\hline \multicolumn{2}{|c|}{$\mathrm{H}_{2} \mathrm{O} / \mathrm{H}_{2}{ }^{18} \mathrm{O}$} & 1.6 & 2.1 & & 3.1 & 3.1 & & 4.6 & 5.0 & & 4.4 & 4.1 & & 1.2 & 1.4 & \\
\hline
\end{tabular}

${ }^{a}$ The concentrations are relative concentrations with respect to the total concentration of the nitrogen compounds mentioned in the table. The compositions of the starting gas mixtures are as follows: part I, $\left.[\mathrm{NO}]_{i}=[\mathrm{NH} 3]_{i}=500 \mathrm{ppm} ;{ }^{18} \mathrm{O} 2\right]_{i}=581 \mathrm{ppm}$; part II, $[\mathrm{NO}]_{i}=500 \mathrm{ppm}$; $\left[{ }^{15} \mathrm{NH} 3\right]_{i}=473 \mathrm{ppm} ;\left[{ }^{18} \mathrm{O} 2\right]_{i}=581 \mathrm{ppm} ;$ part III, $[\mathrm{NO}]_{i}=500 \mathrm{ppm} ;\left[{ }^{15} \mathrm{NH} 3\right]_{i}=473 \mathrm{ppm} ;[\mathrm{O} 2]_{i}=495 \mathrm{ppm}$. In all parts of the experiments, the

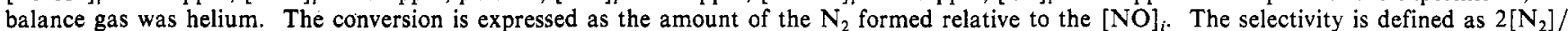
$\sum[\mathrm{N}]$ for part I and $\left[{ }^{15} \mathrm{NN}\right] / \Sigma\left[{ }^{15} \mathrm{~N}\right]$ for part III. ${ }^{b}$ The figures of part II for the $\mathrm{V}_{2} \mathrm{O}_{5}$ on $\mathrm{TiO}_{2}$ catalyst were taken at 20 min. With respect to the isotopic composition, the catalyst was not at steady state. 'Time after which the steady state was attained and also at which the figures were taken.

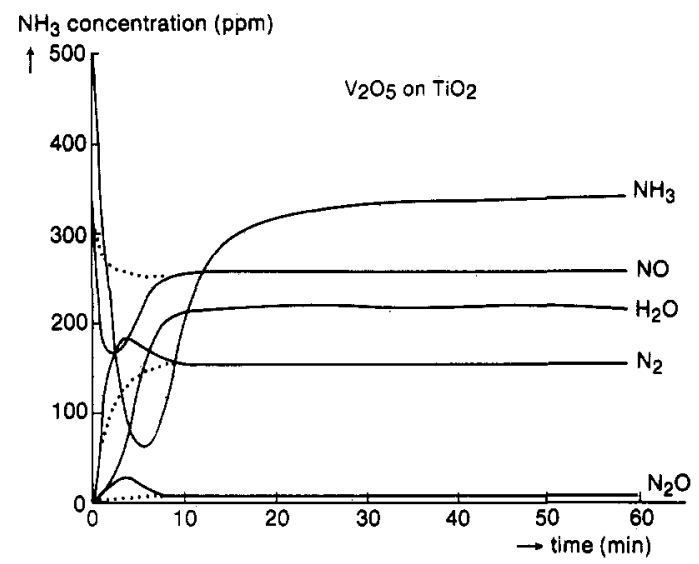

Figure 3. Concentration profiles as a function of time for the products $\mathrm{NH}_{3}, \mathrm{NO}, \mathrm{H}_{2} \mathrm{O}, \mathrm{N}_{2}$, and $\mathrm{N}_{2} \mathrm{O}$ of the reaction of $\mathrm{NO}$ and $\mathrm{NH}_{3}$ at 400 ${ }^{\circ} \mathrm{C}$ on the $\mathrm{V}_{2} \mathrm{O}_{5}$ on $\mathrm{TiO}_{2}$ catalyst, after the catalyst was treated with $\mathrm{NH}_{3}$ in helium for $13 \mathrm{~h}$ at $400^{\circ} \mathrm{C}$ (see also Figure 2). $[\mathrm{NO}]_{i}=\left[\mathrm{NH}_{3}\right]_{i}=500$ ppm, balance helium.

observed when a mixture of $\mathrm{NO}$ and $\mathrm{NH}_{3}$ was admitted to the catalyst at $400^{\circ} \mathrm{C}$. Extra NO was thus consumed and extra $\mathrm{N}_{2}$ and some $\mathrm{N}_{2} \mathrm{O}$ were produced initially. The steady-state concentration of $\mathrm{NO}$ was lower than that of the $\mathrm{NH}_{3}$ concentration, because NO was needed to reoxidize the oxygen vacancies. According to the material balance, the predominant overall reaction to occur is

$$
6 \mathrm{NO}+4 \mathrm{NH}_{3} \rightarrow 5 \mathrm{~N}_{2}+6 \mathrm{H}_{2} \mathrm{O}
$$

The integrated area of the "overshoot peak" of NO, the area between the full and the dotted curve for NO in Figure 3, is roughly equal to the sum of the integrated areas of the equivalent overshoot peaks of $\mathrm{N}_{2} \mathrm{O}$ and $\mathrm{N}_{2}$. The phenomenon of the overshoot of NO, $\mathrm{N}_{2}$, and $\mathrm{N}_{2} \mathrm{O}$ appears to arise from the reaction of the NO with nitrogen-containing species already present at the surface as a resullt of the reduction. The water profile shows no overshoot, as can be seen in Figure 3, and we thus conclude that there is no oxygen available on the surface after the reaction with ammonia for the overall reaction:

$$
4 \mathrm{NO}+4 \mathrm{NH}_{3}+\mathrm{O}_{2} \rightarrow 4 \mathrm{~N}_{2}+6 \mathrm{H}_{2} \mathrm{O}
$$

Such a reaction was found when a calcined catalyst was used. ${ }^{1}$ Similar experiments were carried out with a mixture of NO and
$\mathrm{V}_{2} \mathrm{O}_{5}$ on $\mathrm{SiO}_{2} / \mathrm{Al}_{2} \mathrm{O}_{3}$

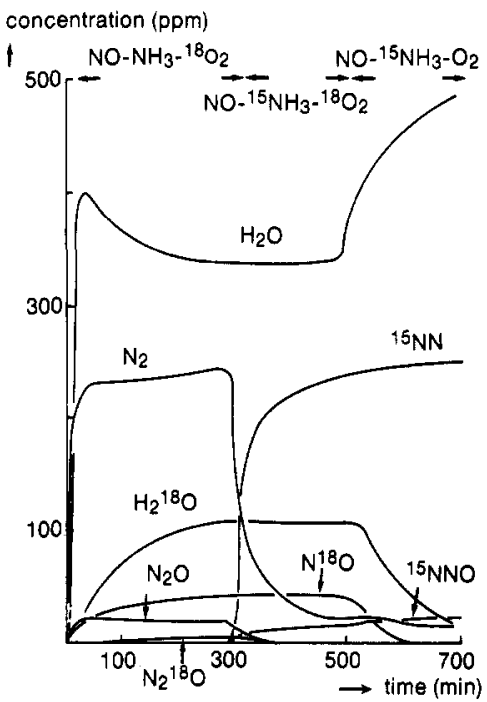

Figure 4. Concentration profiles as a function of time for $\mathrm{H}_{2} \mathrm{O}, \mathrm{N}_{2}$, $\mathrm{H}_{2}^{18} \mathrm{O}, \mathrm{N}^{18} \mathrm{O}, \mathrm{N}_{2} \mathrm{O},{ }^{15} \mathrm{NN}$, and ${ }^{15} \mathrm{NNO}$ over the catalyst $\mathrm{V}_{2} \mathrm{O}_{5}$ on $\mathrm{SiO}_{2} / \mathrm{Al}_{2} \mathrm{O}_{3}$. In the period $0-290 \mathrm{~min}$, the incoming gas composition is $500 \mathrm{ppm} \mathrm{NO} ; 500 \mathrm{ppm} \mathrm{NH} \mathrm{NH}_{3} ; 581 \mathrm{ppm}{ }^{18} \mathrm{O}_{2}$. In the periods $290-490 \mathrm{~min}$ and 490-690 min, the initial concentrations were $500 \mathrm{ppm} \mathrm{NO}, 473 \mathrm{ppm}$ ${ }^{15} \mathrm{NH}_{3}, 581 \mathrm{ppm}{ }^{18} \mathrm{O}_{2}$; and $500 \mathrm{ppm} \mathrm{NO}, 473 \mathrm{ppm}{ }^{15} \mathrm{NH}_{3}, 495 \mathrm{ppm} \mathrm{O}$, respectively. Temperature $400^{\circ} \mathrm{C}$; balance helium (see also Table I).

${ }^{15} \mathrm{NH}_{3}$ on the samples of $\mathrm{V}_{2} \mathrm{O}_{5}$ on $\mathrm{Al}_{2} \mathrm{O}_{3}$ (no. 4) and the $\mathrm{V}_{2} \mathrm{O}_{5}$ on $\mathrm{TiO}_{2}$ catalysts after reduction with ${ }^{15} \mathrm{NH}_{3}$ (Table II). In these cases the reaction products were found to be ${ }^{15} \mathrm{NN},{ }^{15} \mathrm{NNO}$, and $\mathrm{H}_{2} \mathrm{O}$. The products $\mathrm{N}_{2}$ and $\mathrm{N}_{2} \mathrm{O}$ were thus produced exclusively from equimolar quantities of $\mathrm{NO}$ and $\mathrm{NH}_{3}$. Minor quantities (about $10^{-9} \mathrm{~mol}$ ) of $\mathrm{N}_{2} \mathrm{O}$ and $\mathrm{N}_{2}$ were also observed during the reaction which suggests that there is some interaction of NO with the surface of the catalyst. However, when oxygen was added to the gas mixtures, no $\mathrm{N}_{2}$ or $\mathrm{N}_{2} \mathrm{O}$ was formed.

The Reaction of $\mathrm{NO}, \mathrm{NH}_{3}$, and $\mathrm{O}_{2}$ over the Prereduced Catalysts. Figure 4 gives an example the results of transient measurements of the selective catalytic reduction of $\mathrm{NO}$ with $\mathrm{NH}_{3}$ at $400{ }^{\circ} \mathrm{C}$ in the presence of oxygen on the catalyst $\mathrm{V}_{2} \mathrm{O}_{5}$ on $\mathrm{SiO}_{2} / \mathrm{Al}_{2} \mathrm{O}_{3}$. During the experiments, which can be divided into three parts, the concentrations of the components were abruptly changed in the following sequence: part $\mathrm{I}, \mathrm{NO}, \mathrm{NH}_{3},{ }^{18} \mathrm{O}_{2}$; part 


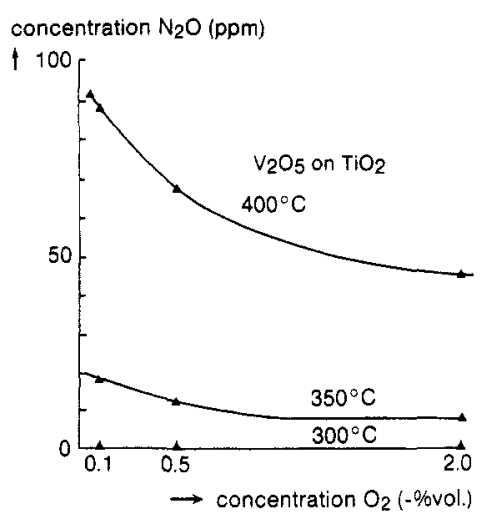

Figure 5. $\mathrm{N}_{2} \mathrm{O}$ concentration as a function of oxygen concentration at three temperatures on the catalyst $\mathrm{V}_{2} \mathrm{O}_{5}$ on $\mathrm{TiO}_{2} .[\mathrm{NO}]_{i}=\left[\mathrm{NH}_{3}\right]_{i}=$ $500 \mathrm{ppm}$, balance helium.

II, NO, ${ }^{15} \mathrm{NH}_{3},{ }^{18} \mathrm{O}_{2}$; part III, NO, ${ }^{15} \mathrm{NH}_{3}, \mathrm{O}_{2}$. Because of the inequality of the concentrations of ${ }^{18} \mathrm{O}_{2}$ and ${ }^{16} \mathrm{O}_{2}$ and of ${ }^{15} \mathrm{NH}_{3}$ and $\mathrm{NH}_{3}$, the conversions of $\mathrm{NO}$ are not the same in the three parts (Table I). As already mentioned in the preceding paper, ${ }^{2}$ the $\mathrm{H}_{2}{ }^{18} \mathrm{O}$ concentration increases as the $\mathrm{H}_{2} \mathrm{O}$ concentration decreases. When $\mathrm{NH}_{3}$ in the feed was replaced after about 300 min by ${ }^{15} \mathrm{NH}_{3}$ (Figure 4), the $\mathrm{N}_{2} \mathrm{O}$ and $\mathrm{N}_{2}{ }^{18} \mathrm{O}$ of the product stream were replaced completely by the respective isotopic nitrous oxide isomers, ${ }^{15} \mathrm{NNO}$ and ${ }^{15} \mathrm{NN}{ }^{18} \mathrm{O}$. The oxygen atom in ${ }^{15} \mathrm{NNO}$ remained attached to a nitrogen atom with which it was associated in the NO molecule. ${ }^{15} \mathrm{NN}^{18} \mathrm{O}$ is thus probably coming from a scrambling of ${ }^{15}$ NNO with a catalyst surface containing oxygen-18. No formation of ${ }^{15} \mathrm{~N}_{2} \mathrm{O}$ or ${ }^{15} \mathrm{~N}_{2}^{18} \mathrm{O}$ has been found with any of the catalysts and this means that the ${ }^{15} \mathrm{NH}_{3}$ was not oxidized to ${ }^{15} \mathrm{~N}_{2} \mathrm{O}$ over the catalyst. Table II summarizes the concentration of a number of the compounds found during the transient studies of the type described above on the five catalysts examined. With respect to $\mathrm{N}_{2} \mathrm{O}$ formation, all the catalysts showed the same behavior. The phenomena which appeared in the different parts of the experiments can be described as follows. Part I for each catalyst gives the concentration of some of the products of the reaction of $\mathrm{NO}, \mathrm{NH}_{3}$, and ${ }^{18} \mathrm{O}_{2}$. On all the catalysts, $\mathrm{N}^{18} \mathrm{O}, \mathrm{N}_{2}, \mathrm{H}_{2}{ }^{18} \mathrm{O}$ and $\mathrm{N}_{2} \mathrm{O}$ were formed. $\mathrm{N}_{2}{ }^{18} \mathrm{O}$ was only found in large amounts on unsupported $\mathrm{V}_{2} \mathrm{O}_{5}$ and on $\mathrm{V}_{2} \mathrm{O}_{5}$ on $\mathrm{TiO}_{2}$. In part II $\left(\mathrm{NH}_{3}\right.$ is switched to $\left.{ }^{15} \mathrm{NH}_{3}\right)$ of the experiments summarized in Table II the same compounds as in part I were formed, in addition to ${ }^{15} \mathrm{NN}$ and ${ }^{15} \mathrm{NNO}$. On two of the catalysts, $\mathrm{V}_{2} \mathrm{O}_{5}$ and $\mathrm{V}_{2} \mathrm{O}_{5}$ on $\mathrm{TiO}_{2}, \mathrm{~N}_{2}{ }^{18} \mathrm{O}$ and ${ }^{15} \mathrm{NN}^{18} \mathrm{O}$ were also formed. The change of concentration of ammonia did not occur as an ideal step function, because of the presence in the system of adsorbed $\mathrm{NH}_{3}$. All the values presented in Table II were taken at steady state; except for those of part II of the $\mathrm{V}_{2} \mathrm{O}_{5}$ on $\mathrm{TiO}_{2}$ catalyst these values were taken at $20 \mathrm{~min}$. In part III, the reaction of NO, ${ }^{15} \mathrm{NH}_{3}$, and $\mathrm{O}_{2}$ gave predominantly the compounds ${ }^{15} \mathrm{NN}$ and ${ }^{15} \mathrm{NNO}$ and to a lesser extent $\mathrm{N}_{2}$ and $\mathrm{N}_{2} \mathrm{O}$. The mass spectrometer is able to distinguish between $\mathrm{N}^{15} \mathrm{NO}$ and ${ }^{15} \mathrm{NNO}{ }^{3}$ These compounds show fragment ions at $m / e 31$ and $m / e 30$, respectively; it was established that no $\mathrm{N}^{15} \mathrm{NO}$ was formed. On the other catalysts, only $\mathrm{N}^{18} \mathrm{O}(m / e 32), \mathrm{N}_{2} \mathrm{O}(m / e 44)$, and ${ }^{15} \mathrm{NNO}(m / e$ 45) were formed. The selectivities of ${ }^{15} \mathrm{NN}$ relative to that of ${ }^{15} \mathrm{NNO}$ (defined as $\left(\left[{ }^{15} \mathrm{NN}\right]\right) /\left(\left[{ }^{15} \mathrm{NN}\right]+\left[{ }^{15} \mathrm{NNO}\right]\right)$ ) for the reaction of $\mathrm{NO},{ }^{15} \mathrm{NH}_{3}$, and $\mathrm{O}_{2}$ for the catalysts 1-5 (Table I part III) were $0.76,0.92,0.98$, and 0.31 . From these results, it appears that if the specific surface area of the catalyst increases, the selectivity to ${ }^{15} \mathrm{NN}$ also increases. It is shown in Figure 5 for the catalyst $\mathrm{V}_{2} \mathrm{O}_{5}$ on $\mathrm{TiO}_{2}$, that the amount of $\mathrm{N}_{2} \mathrm{O}$ formed depends on the gaseous oxygen concentration; as the oxygen concentration decreases, the nitrous oxide concentration increases.

The best fit of the curve of Figure 5 was found to be a logarithmic function of the form

$$
\left[\mathrm{N}_{2} \mathrm{O}\right]=55.4-13.1 \ln \left[\mathrm{O}_{2}\right]
$$

in the oxygen concentration range $0.05-2$ vol $\% \mathrm{O}_{2}$. The dependence of $\mathrm{N}_{2} \mathrm{O}$ on the oxygen concentration was less marked

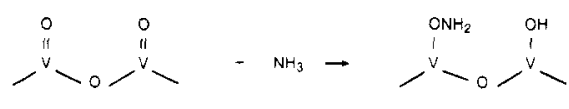

A

D

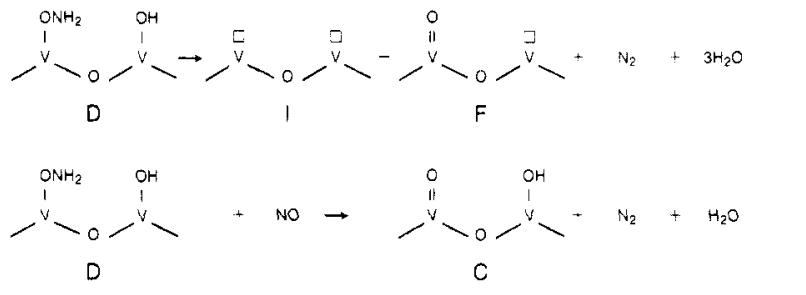

$\underset{\substack{\mathrm{ONH}_{2} \\ 1}}{\mathrm{ON}_{\mathrm{O}}^{\mathrm{II}}}$

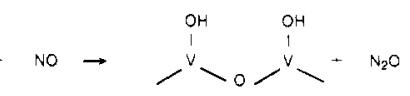

B

$$
\text { 2NO } \rightarrow
$$<smiles>CN(O)OP(=O)(O)ON(C)ON</smiles><smiles>CN(O)OP(C)O</smiles>

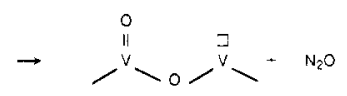

$\mathrm{F}$
Figure 6. Proposed sequence of reactions for the reduction of NO by $\mathrm{NH}_{3}$ over a supported vanadia catalyst to form $\mathrm{N}_{2}, \mathrm{H}_{2} \mathrm{O}$, and $\mathrm{N}_{2} \mathrm{O}$. Reactions 1 and 3 were discussed in a previous paper. ${ }^{2}$ For the nomenclature of the various species the same symbols are used as in ref 2 .

at lower temperatures. ${ }^{15} \mathrm{NN}$ and ${ }^{15} \mathrm{NNO}$ were formed on the catalysts (part III, Table II); no reaction occurs in the absence of catalyst. ${ }^{15} \mathrm{~N}_{2}(m / e 30)$ is likely to be formed but could not be detected in the experiments because its mass coincides with the mass of nitric oxide. Preliminary experiments with mixtures of ${ }^{15} \mathrm{NO}, \mathrm{NH}_{3}$, and $\mathrm{O}_{2}$ over the unsupported $\mathrm{V}_{2} \mathrm{O}_{5}$ and $\mathrm{V}_{2} \mathrm{O}_{5}$ on $\mathrm{TiO}_{2}$ catalysts have shown that ${ }^{15} \mathrm{~N}_{2}$ could be produced in relatively large amounts: about $6 \%$ of the total amount of nitrogen formed. From Table II, it follows that NO shows interaction with the labeled catalyst surface, because of the formation of $\mathrm{N}^{18} \mathrm{O}(\mathrm{m} / \mathrm{e}$ 32). However, no ${ }^{15} \mathrm{~N}^{18} \mathrm{O}$, a possible reaction product of ${ }^{15} \mathrm{NH}_{3}$ with the surface oxygen, was found.

\section{Discussion}

As was discussed in the preceding paper, ${ }^{2}$ three important items are involved in a series of reactions $\mathrm{NO}, \mathrm{NH}_{3}$, and $\mathrm{O}_{2}$. First, the formation of water occurs both by a dehydration step and by an Eley-Rideal mechanism. Second, the formation of nitrogen, which is produced from nitric oxide and ammonia, occurs via an EleyRideal mechanism. Third, nitrous oxide is also formed out of one molecule of nitric oxide and one molecule of ammonia. The formation of water was discussed in detail in the preceding paper. ${ }^{2}$ A number of reactions are added to those previously presented to explain the formation of nitrous oxide. The most important reactions are summarized in Figure 6. These reaction sequences help us to explain our ideas about the reaction mechanism. For the nomenclature of the various species the same symbols are used as in the preceding paper. ${ }^{2}$

The Interaction of $\mathrm{NH}_{3}$ with the Oxidic Surface. We postulate that ammonia chemisorbs on the surface at $400^{\circ} \mathrm{C}$ according to reaction 1 shown in Figure 6 resulting in a nitrogen-containing species and an $\mathrm{OH}$ group. The presence of an $\mathrm{NH}_{2}$ species on the surface has been suggested by several authors. ${ }^{2-4}$ The arrangement of atoms such as $\mathrm{V}-\mathrm{ONH}_{2}$ was chosen because of the hypothesis that $\mathrm{V}-\mathrm{ONH}_{2}$ could be formed from the reaction of $\mathrm{NH}_{2} \mathrm{OH}$ and a hydroxyl group on the surface of the oxide. However, we have no experimental evidence or proof of its presence yet.

(3) Otto, K.; Shelef, M.; Kummer, J. T. J. Phys. Chem. 1970, 74, 2690.

(4) Miyamoto, A.; Kobayashi, K.; Inomata, M.; Murakami, Y. J. Phys. Chem. 1982, 86, 2945. 
Subsequent reaction of this dissociated ammonia species in the presence of NO does not lead to the oxidation preadsorbed ${ }^{15} \mathrm{~N}$ containing species, because no ${ }^{15} \mathrm{~N}_{2},{ }^{15} \mathrm{NO},{ }^{15} \mathrm{~N}^{18} \mathrm{O},{ }^{15} \mathrm{~N}_{2} \mathrm{O}$, or ${ }^{15} \mathrm{~N}_{2}{ }^{18} \mathrm{O}$ was found on the $\mathrm{V}_{2} \mathrm{O}_{5}$ on $\mathrm{Al}_{2} \mathrm{O}_{3}$ and $\mathrm{V}_{2} \mathrm{O}_{5}$ on $\mathrm{SiO}_{2} / \mathrm{Al}_{2} \mathrm{O}_{3}$ catalysts (Table II). On the $\mathrm{V}_{2} \mathrm{O}_{5}$ and $\mathrm{V}_{2} \mathrm{O}_{5}$ on $\mathrm{TiO}_{2}$ catalysts, oxidation of ${ }^{15} \mathrm{NH}_{3}$ to ${ }^{15} \mathrm{~N}_{2}$ was able to occur. It is suggested here that chemisorbed ammonia in the absence of NO leads to the oxidation/dehydration of the surface species $\mathrm{D}$ forming species $\mathrm{F}$ and $\mathrm{I}$ (reaction 2). At $400^{\circ} \mathrm{C}, \mathrm{NH}_{3}$ is thus oxidized and $\mathrm{V}(\mathrm{V})$ is reduced to $\mathrm{V}(\mathrm{IV})$ according to the overall stoichiometry

$$
3 \mathrm{~V}_{2} \mathrm{O}_{5}+2 \mathrm{NH}_{3} \rightarrow \mathrm{N}_{2}+3 \mathrm{H}_{2} \mathrm{O}+3 \mathrm{~V}_{2} \mathrm{O}_{4}
$$

Ammonia is selectively oxidized to $\mathrm{N}_{2}$ and $\mathrm{H}_{2} \mathrm{O}$ and not to $\mathrm{N}_{2} \mathrm{O}$. From the amounts of ammonia reacted (see Results and Interpretation) it can be calculated that 0.24 and 0.12 molecules ammonia per vanadium atom were consumed for the $\mathrm{V}_{2} \mathrm{O}_{5}$ on $\mathrm{TiO}_{2}$ (no. 1) and $\mathrm{V}_{2} \mathrm{O}_{5}$ on $\mathrm{Al}_{2} \mathrm{O}_{3}$ (no. 4) catalysts, respectively, and that the calculated number of oxygen removed per vanadium atom were 0.36 and 0.18 , respectively. In the previous paper, ${ }^{2}$ it was calculated that up to a maximum of half of the surface area could be covered by $\mathrm{OH}$ groups during the reaction of $\mathrm{NO}, \mathrm{NH}_{3}$, and $\mathrm{O}_{2}$. This implies also that a maximum of half of the adsorption sites could be occupied by $\mathrm{NH}_{i}$ species. In the experiments on the reduction of the catalysts with ammonia, this proportion is lower because of the formation of molecular nitrogen from two adjacent nitrogen atoms. This can be explained by suggesting that a nitrogen atom present on the oxide surface must become paired with another $\mathrm{N}$ atom present on the surface so that recombination into an $\mathrm{N}_{2}$ molecule and desorption of it may occur. However, in order that nitrogen atoms can be adsorbed and subsequently combine with one another an uninterrupted layer of oxygen atoms is necessary. During the reduction, the number of oxygen vacancies increases and these are not refilled by oxygen atoms as is the case when oxygen or nitric oxide is present in the gas phase. Another important point is that two adjacent lattice oxygen atoms are needed for the chemisorption of an $\mathrm{NH}_{i}$ species and an $\mathrm{H}$ atom (species $\mathrm{A}$ in Figure 6):

$$
\mathrm{NH}_{3}(\mathrm{~g})=\mathrm{NH}_{3}(\mathrm{ad})=\mathrm{NH}_{2}(\mathrm{ad})+\mathrm{H}(\mathrm{ad})
$$

$\left(\mathrm{NH}_{2}\right)$ ad can then react further on the surface, according to the equation

$$
\mathrm{NH}_{2}(\mathrm{ad})=\mathrm{NH}(\mathrm{ad})+\mathrm{H}(\mathrm{ad})
$$

It was found by reaction of NO with the prereduced catalyst that $20 \%$ of the ammonia used for reduction still remained as nitrogen-containing species on the surface after $1 \mathrm{~h}$ of reduction and a further hour of flushing the catalyst with helium. The nitrogen-containing species disappeared when the catalyst was heated in helium for more than $3 \mathrm{~h}$. The helium used contained traces of oxygen and this probably restored the oxygen vacancies on the surfaces and thus permitted the nitrogen atoms to combine to give $\mathrm{N}_{2}$. Haber et al. ${ }^{5}$ used hydrogen to reduce a monolayer $\mathrm{V}_{2} \mathrm{O}_{5}$ on $\mathrm{TiO}_{2}$ (anatase) catalyst at $400^{\circ} \mathrm{C}$ and found one oxygen atom was removed for each vanadium polyhedron and that the number of oxygen atoms which can be removed from each $\mathrm{VO}_{4}$ polyhedron is independent of the nature of the reducing agent $\left(\mathrm{H}_{2}, \mathrm{CO}\right.$, or hydrocarbons). However, in our case, reducing the catalyst with ammonia results in removal of about one oxygen atom per two vanadium atoms. After reducing the catalyst with ammonia and then flushing the reduced material for $3 \mathrm{~h}$ and introducing NO, or $\mathrm{NO}$ and $\mathrm{NH}_{3}$, it was suggested in our previous paper ${ }^{2}$ that $\mathrm{N}_{2}$ and $\mathrm{N}_{2} \mathrm{O}$ were formed by an Eley-Rideal mechanism (reactions 3 and 4 in Figure 6).

It was found in this work and in the previous paper ${ }^{2}$ that whether or not oxygen was used, most of the nitrogen $\left(\mathbf{N}_{2}\right)$ as well as the nitrous oxide $\left(\mathrm{N}_{2} \mathrm{O}\right)$ formed arises mainly from one molecule of $\mathrm{NO}$ and one molecule of $\mathrm{NH}_{3}$. Equivalent results have been reported for experiments carried out in the absence of oxygen; ${ }^{4,6-8}$

(5) Haber, J.; Koziowska, A.; Kozlowski, R. J. Catal. 1986, 102, 52. (6) Mizumoto, M.; Yamazoe, N.; Seiyama, T. J. Catal. 1978, 55, 119.

(7) Williamson, W. B.; Lunsford, J. H. J. Phys. Chem. 1976, 80, 2664. in these investigations minor quantities of $\mathrm{N}_{2}$ and $\mathrm{N}_{2} \mathrm{O}$ were formed, probably by reaction paths 5 and 6 . Miyamoto et al. ${ }^{4}$ studied the reaction of ${ }^{15} \mathrm{NO}$ and $\mathrm{NH}_{3}$ on unsupported $\mathrm{V}_{2} \mathrm{O}_{4}$ at $350{ }^{\circ} \mathrm{C}$. They found in the exhaust $\mathrm{N}^{15} \mathrm{~N}$ and $\mathrm{N}^{15} \mathrm{NO}$ as well as large amounts of ${ }^{15} \mathrm{~N}_{2}$, the latter coming from the reduction of ${ }^{15} \mathrm{NO}$ by the $\mathrm{V}_{2} \mathrm{O}_{4}$ catalyst. From these results, we conclude that the reduced supported $\mathrm{V}_{2} \mathrm{O}_{5}$ catalysts of this work cannot be compared with unsupported $\mathrm{V}_{2} \mathrm{O}_{4}$ with respect to the behavior during the reaction of $\mathrm{NO}$ and $\mathrm{NH}_{3}$ in the absence of oxygen. With respect to the reoxidation of the reduced sites of the catalyst, NO competes with $\mathrm{O}_{2}$. However, the reaction of oxygen is faster than the reaction of nitric oxide with the catalyst. ${ }^{1,2}$ In the absence of oxygen, two "types" of $\mathrm{N}_{2}$ and $\mathrm{N}_{2} \mathrm{O}$ were formed from the reaction of $\mathrm{NO}$ or of $\mathrm{NO}$ and $\mathrm{NH}_{3}$ with the catalyst according to the reactions 3-6 as shown in Figure 6. Three "types" of nitrogen were formed: (i) from the reaction of NO and chemisorbed ammonia (reaction 3); (ii) from the oxidation of $\mathrm{NH}_{3}$ (reaction 1 and 2); and (iii) from the reduction of NO to $\mathrm{N}_{2}$ (reaction 5). The selectivity of the second reaction, the oxidation of $\mathrm{NH}_{3}$ to $\mathrm{N}_{2}$, appears to be determined by the probability that two chemisorbed nitrogen species are adsorbed on adjacent sites. In the presence of oxygen, the third reaction does not occur. Species $J$ shows NO coordinated via its oxygen end to an oxygen vacancy on the catalyst, analogous to the adsorption of nitric oxide on cerium oxide as reported by Niwa et al. ${ }^{10}$ They observed that, on a partially reduced site, $\mathrm{NO}$ forms a chelating $\mathrm{NO}_{2}$ species and that the hyponitrite ion as another adsorbed species was a precursor of $\mathrm{N}_{2}$ and $\mathrm{N}_{2} \mathrm{O}$ by adsorption of NO. However, more data and studies are needed in order to establish this surface arrangement.

Oxygen Exchange between $\mathrm{NO}$ and the Catalyst. $\mathrm{N}^{18} \mathrm{O}$ comes exclusively from scrambling of NO with the surface. ${ }^{2}$ Extra evidence for this conclusion is the lack of ${ }^{15} \mathrm{~N}^{18} \mathrm{O}$ during the experiments. The amount of $\mathrm{N}^{18} \mathrm{O}$ at the outlet of the reactor is independent of the specific surface area or the amount of catalyst used. It probably depends on the number of oxygen vacancies adjacent to lattice ${ }^{18} \mathrm{O}$. From kinetic measurements with a continuous stirred tank reactor, we have previously found a reaction order of 0.7 for NO, which suggests interaction of NO with the surface. Shelef' observed that the whole monolayer of oxygen and even some subsurface oxygen ions can be exchanged at increasing temperatures. He suggested that surface nitrite ions or nitro complexes served as surfaces intermediates. The present results show that $\mathrm{N}^{18} \mathrm{O}$ can be formed when ${ }^{18} \mathrm{O}_{2}$ is used in the gas phase after ${ }^{18} \mathrm{O}$ has been built into the surface oxygen layer of the catalyst. The $\mathrm{N}^{18} \mathrm{O}$ formed reacts with $\mathrm{NH}_{3}$ via the Eley-Rideal mechanism as was suggested in our previous paper, ${ }^{2}$ forming $\mathrm{N}_{2}$ and $\mathrm{H}_{2}{ }^{18} \mathrm{O}$. From the reaction

$$
4 \mathrm{NO}+4 \mathrm{NH}_{3}+{ }^{18} \mathrm{O}_{2} \rightarrow 4 \mathrm{~N}_{2}+4 \mathrm{H}_{2} \mathrm{O}+2 \mathrm{H}_{2}{ }^{18} \mathrm{O}
$$

it follows that the stoichiometric ratio of $\mathrm{H}_{2} \mathrm{O}$ to $\mathrm{H}_{2}{ }^{18} \mathrm{O}$ should be 2. This ratio was found to have values of about 1.2 and 1.6 for the unsupported $\mathrm{V}_{2} \mathrm{O}_{5}$ and $\mathrm{V}_{2} \mathrm{O}_{5}$ on $\mathrm{TiO}_{2}$ catalysts respectively; however, for the other three catalysts, the value was between three and five (Table II). From this, it can be calculated, for the cases of the unsupported $\mathrm{V}_{2} \mathrm{O}_{5}$ and of $\mathrm{V}_{2} \mathrm{O}_{5}$ on $\mathrm{TiO}_{2}$, that the contribution of the reaction of $\mathrm{N}^{18} \mathrm{O}$ and $\mathrm{NH}_{3}$ to give $\mathrm{H}_{2}{ }^{18} \mathrm{O}$ are about $18 \%$ and $8 \%$, respectively; it can also be calculated that 90 and $40 \mathrm{ppm}$, respectively, of NO were converted to $\mathrm{N}^{18} \mathrm{O}$ during the reaction. It can thus be concluded that NO interacts with the surface during the selective reduction reaction.

Formation of $\mathrm{N}_{2} \mathrm{O}$. The amount of $\mathrm{N}_{2} \mathrm{O}$ produced is inversely proportional to both the oxygen concentration and the specific surface area. If the surface area is smaller, the density of adjacently adsorbed nitric oxide molecules increases to a point where denitration and consequent formation of $\mathrm{N}_{2} \mathrm{O}$ sets in (reaction

(8) Yoshida, S.; Tarama, K. Ind. Eng. Chem. Product Res. Dev. 1979, 18 , 283.

(9) Shelef, M. Catal. Rev.-Sci. Eng. 1975, 11, 1.

(10) Niwa, M.; Furukawa, Y.; Murakami, Y. J. Colloid Interface Sci. $1982,86,260$. 
5). On the catalyst $\mathrm{V}_{2} \mathrm{O}_{5}$ on $\mathrm{TiO}_{2}$, small amounts of $\mathrm{N}_{2}$ and $\mathrm{N}_{2} \mathrm{O}$ were formed (Table II); this results from the reoxidation of the reduced catalyst surface with NO according to reactions 5 and 6 of Figue 6. Going from $\mathrm{V}_{2} \mathrm{O}_{5}\left(S_{\mathrm{BET}}=10.5 \mathrm{~m}^{2} / \mathrm{g}\right)$ to $\mathrm{V}_{2} \mathrm{O}_{5}$ on $\mathrm{TiO}_{2}\left(S_{\mathrm{BET}}=45 \mathrm{~m}^{2} / \mathrm{g}\right)$ the selectivities of $\mathrm{N}_{2}{ }^{18} \mathrm{O}$ toward $\mathrm{N}_{2} \mathrm{O}$ and ${ }^{15} \mathrm{NN}^{18} \mathrm{O}$ toward ${ }^{15} \mathrm{NNO}$ decrease $50 \%$. This implies that in case of a lower surface area, lattice oxygen becomes more and more involved in the production of $\mathrm{N}_{2} \mathrm{O}$. The density of vacancies is thus enhanced.

\section{Conclusions}

A more detailed mechanism based on the experimental results with nitrogen and oxygen tracers has been proposed for the reaction of $\mathrm{NO}$ with $\mathrm{NH}_{3}$ in the presence of oxygen. Almost every phenomenon observed could be explained by the proposed reaction mechanism.

(i) During the reduction reaction most of the $\mathrm{N}_{2}$ and of the $\mathrm{N}_{2} \mathrm{O}$ are formed from the nitrogen atoms of nitric oxide and ammonia for reaction both in the presence of and in the absence of oxygen. The $\mathrm{N}_{2} \mathrm{O}$ molecule formed consists primarily of the atoms from one molecule of NO attached to a nitrogen atom from $\mathrm{NH}_{3}$. (ii) It is suggested that two molecules of $\mathrm{NO}$ adsorb on a doublet oxygen vacancy with simultaneous release of $\mathrm{N}_{2}$ and $\mathrm{N}_{2} \mathrm{O}$ into the gas phase. When molecular oxygen is present, the formation of $\mathrm{N}_{2}$ and $\mathrm{N}_{2} \mathrm{O}$ from $\mathrm{NO}$ is suppressed. Under reducing conditions, some $\mathrm{N}_{2}$ is formed from $\mathrm{NO}$ and under oxidizing conditions, $\mathrm{N}_{2}$ is formed from ammonia.

(iii) During the reduction reaction, NO shows scrambling with the surface of the catalyst and ammonia is oxidized to molecular nitrogen. This phenomenon is currently being studied further by using labeled NO.

(iv) $\mathrm{N}_{2} \mathrm{O}$ is produced from the reaction of one molecule NO with the nitrogen atom from ammonia on two different sites of the catalysts by a reaction sequence involving gaseous nitric oxide and chemisorbed ammonia and by denitration of the surface. The same holds for the formation of water, which is produced by dehydration of the catalyst surface, as a result of the reaction of $\mathrm{NO}$ and $\mathrm{NH}_{3}$.

(v) The oxygen vacancies are reoxidized more rapidly by $\mathrm{O}_{2}$ than by $\mathrm{NO}$; this explains the enhancing effect of oxygen on the rate of the overall reaction of $\mathrm{NO}, \mathrm{NH}_{3}$, and $\mathrm{O}_{2}$.

Registry No. NO, 10102-43-9; $\mathrm{NH}_{3}, 7664-41-7 ; \mathrm{O}_{2}, 7782-44-7 ; \mathrm{V}_{2} \mathrm{O}_{5}$, 1314-62-1; $\mathrm{TiO}_{2}, 13463-67-7$.

\title{
Physical Adsorption on Patchwlse Heterogeneous Surfaces. 5. Phase Transitions in Krypton Films on Graphitized Carbon Black in the Temperature Range 104-129 K
}

\author{
Toan P. Vo ${ }^{\dagger}$ and Tomlinson Fort, Jr.* ${ }^{\ddagger}$ \\ Department of Chemical Engineering, Carnegie-Mellon University, Pittsburgh, Pennsylvania 15213 \\ (Received: March 17, 1987; In Final Form: June 23, 1987)
}

\begin{abstract}
Adsorption isotherms of krypton on graphitized carbon black were measured with a high-precision volumetric adsorption apparatus in the temperature range of $104.5-129.0 \mathrm{~K}$. Three of the isotherms were measured up to more than five statistical adsorbed layers. Isosteric heats and equilibrium spreading pressures were calculated from the adsorption isotherms and aided interpretation of the data. The existence of both a fluid to in-registry solid and an in-registry solid to out-of-registry solid phase transition in the adsorbed krypton films is clear below $122 \mathrm{~K}$. At temperatures of $122 \mathrm{~K}$ and above the fluid krypton changes continuously to the out-of-registry solid. Thus, a phase diagram enclosing the in-registry solid adsorbed film was defined. The dispersion force contribution to the surface free energy of graphitized carbon black was calculated to be 154.7 $\mathrm{mN} / \mathrm{m}$.
\end{abstract}

\section{Introduction}

Experimental studies of gas adsorption have revealed a variety of phase transitions in the adsorbed films ${ }^{1-4}$ if the substrate is nearly "homogeneous". ${ }^{3}$ One such solid substrate is graphite. Graphitized carbon black ( $\mathrm{gcb}$ ) and some of its variations expose almost exclusively the $(0001)$ lattice plane and consequently have nearly homogeneous surfaces.

If the dimension of the adsorbed gas molecule is compatible with that of the graphite lattice, there may be more than one two-dimensional solid phase. It has been observed that, near the completion of a monolayer, adsorbed krypton may form a twodimensional solid in-registry with the graphite lattice ${ }^{5,6}$ as well as a close-packed film. The phase transition from two-dimensional (2-D) fluid to 2-D in-registry solid, and the rearrangement of the 2-D inregistry solid to form a close-packed film, appear as two steps on the vapor pressure isotherms near the coverage corresponding to monolayer completion. These transitions were first observed by Thomy and Duval, ${ }^{1}$ then by Larher, ${ }^{2}$ and, in this laboratory, by Putnam and Fort ${ }^{3}$ over a temperature range from 77.3 to $108.7 \mathrm{~K}$.

\footnotetext{
${ }^{\dagger}$ Present address: Calgon Carbon Corporation, Pittsburgh, PA 15230.

$\ddagger$ Present address: California Polytechnic State University, San Luis Obispo, CA 93407.
}

The present work was intended primarily to extend our study of krypton adsorption on graphitized carbon black to higher temperatures in an attempt to find the temperature above which we postulated ${ }^{6}$ that the adsorbed 2-D fluid crystallizes directly to the adsorbed 2-D close-packed solid. It was also our goal to define more carefully the part of the 2-D phase diagram which enclosed the registered solid phase. ${ }^{6}$ Finally, from determination of spreading pressures for adsorbed krypton films up to pressures near saturation, we wanted to confirm our previously reported ${ }^{3}$ estimate for the dispersion force contribution to the surface energy of graphitized carbon black.

To these ends, seven new adsorption isotherms were obtained in the temperature range of 104-129 K. Three of the isotherms were measured up to more than five statistical adsorbed layers. Special attention was paid to the phase transition portion of the isotherms, namely, the range of coverage from 100 to about 135

(1) Thomy, A.; Duval, X. J. Chim. Phys. 1970, 67, 1101.

(2) Larher, Y. J. Chem. Soc., Faraday Trans. I 1974, 70, 320.

(3) Putnam, F. A.; Fort, Jr., T. J. Phys. Chem. 1975, 79, 459.

(4) Butler, D. M.; Huff, G. B.; Toth, R. W.; Stewart, G. A. Phys. Rev. Lett. 1975, 35, 1718 .

(5) Thomy, A.; Regnier, J; Duval, X. Colloq. Int. C.N.R.S. 1972, No. 201. 2171 .

6) Putnam, F. A.; Fort, Jr., T.; Griffiths, R. B. J. Phys. Chem. 1977, 81 . 